\title{
Livssituation och förhållningssätt bland äldre i behov av hjälp och stöd
}

\author{
GUNHILD HAMMARSTRÖM \& SANDRA TORRES
}

Denna studie behandlar hur äldre personer i behov av hjälp och stöd $i$ sitt vardagliga liv framställer sin livssituation. Fyra olika förhållningssätt har identifierats utifrån vad de intervjuade berättar om sina funktionsnedsättningar, rumsliga och sociala begränsningar, sociala relationer och socialt stöd samt välbefinnande.

Ekonomiskt stöd har erhållits från dåvarande FoU-Centrum, Kommunförbundet i Uppsala län, Samhällsvetenskapliga fakulteten, Uppsala universitet, och Vetenskapsrådet. Vi vill tacka det gerontologiska seminariet vid Sociologiska institutionen, Uppsala universitet, samt de två anonyma granskare som givit kommentarer på en tidigare version.

Gunhild Hammarström är professor i sociologi vid Uppsala universitet.

Sandra Torres är docent i sociologi och forskarassistent vid Tema Äldre och åldrande, Linköpings universitet.

\section{Studiens begreppsliga och teoretiska utgångspunkter}

Kunskapen om hur äldre människor med funktionsnedsättningar och i behov av hjälp och stöd själva ser på sin livssituation och upplevelse av välbefinnande är ganska begränsad, trots att studier av välbefinnandet bland äldre har blivit alltmer förekommande (t.ex. Horgas et al. 1998). I tidigare forskning har ett vanligt antagande varit att försämrad fysisk funktionsförmåga och åtföljande behov av hjälp och stöd utgör en vändpunkt utifrån vilken män- 
niskors liv tar en ny inriktning. En senare uppfattning är emellertid att det inte är den fysiska funktionsnedsättningen i sig, som avgör hur äldre människor hanterar denna förändring, utan snarare den subjektiva upplevelsen av den. Vissa forskare har poängterat människornas attityder och anpassningsförmåga till den nya situationen, medan andra har tagit fasta på de strategier olika människor använder sig av för att bemöta och erhålla kontroll över sin situation, och där även en minskning av aktiviteter kan bidra till välbefinnande. (Antonucci \& Akiyama 1997, Baltes \& Horgas 1997, Diehl 1998, Pitcher \& Hong 1986, Willis 1991).

Eftersom fysiska och psykiska funktionsnedsättningar bemöts på olika sätt av olika personer, är det stora individuella variationer i hur äldre människor hanterar sitt vardagliga liv. För att synliggöra den heterogenitet som finns, är syftet med denna studie att utifrån begreppet vardagskompetens belysa hur äldre i behov av hjälp och stöd på grund av fysiska funktionsnedsättningar själva ser på sin livssituation. Begreppet vardagskompetens har i tidigare forskning inriktats på förmågan att utföra instrumentella dagliga aktiviteter, medan en senare definition inkluderar inte bara en persons förmåga att utföra de aktiviteter, som är väsentliga för ett självständigt boende, utan även individens potential att utföra vissa uppgifter samt dennes förmåga att handha mellanmänskliga relationer och socialt stöd, dvs både fysiska, psykiska och sociala komponenter (Diehl 1998, Willis 1991).

I analysen har vi inspirerats av bl.a. Willis' (1991) teoretiska modell över hur vardagskompetens kan studeras. Modellen inbegriper fyra olika dimensioner, som är ömsesidigt relaterade till varandra. En dimension består av de ovan nämnda komponenterna. En ytterligare dimension utgörs av de förhållanden som föregår de ovan nämnda komponenterna såsom individens fysiska och kognitiva förmåga. Den tredje dimensionen består av faktorer som individens motivation samt föreställningar om sin egen förmåga att kunna påverka och ha kontroll över sin situation. Den fjärde och sista dimensionen utgör själva utfallet i form av fysiskt och psykiskt välbefinnande. En äldre persons välbefinnande antas alltså delvis hänga samman med förmågan att hantera olika fysiska, psykiska och sociala förhållanden och upplevelsen av att själv kunna påverka sin situation.

Betydelsen av sociala relationer, socialt stöd och känslan av att ha kontroll över situationen för äldres välbefinnande betonas även av ett flertal andra forskare (bl.a. Antonucci \& Akiyama 1997, Baltes \& Horgas 1997, Carstensen 1992, Carstensen \& Lang 1997, Pitcher \& Hong 1986). Den främsta källan till socialt stöd och hjälp har oftast visat sig vara den nära familjen. Bilden av familjens betydelse är emellertid inte entydig. Bland annat har känslor av ambivalens och stress påvisats mellan vårdbehövande föräldrar och deras vuxna barn, liksom i förhållandet mellan makar, i synnerhet i de fall där den ena parten är i behov av vård (Antonucci \& Akiyama 1997, Lüscher \& Pillemer 1998). Studier har också visat att det kan vara ytterst besvärande för gamla människor att i ökande grad bli beroende av andra människors stöd och hjälp, inklusive nära anhöriga, för att klara sitt 
dagliga liv, eftersom det kan innebära en social kostnad att både ta emot och be om hjälp (Hansson \& Carpenter 1994, Heckhausen \& Lang 1996). De som däremot har en subjektiv föreställning av att ha kontroll över sin situation och att kunna påverka det sociala utbytet kan dock ta emot stöd utan att uppleva det som ett hot mot det egna jaget. De som inte tycker sig ha denna kontroll kan i stället känna sig belastade av hjälpen. Den äldres upplevelse av att ha kontroll i sina sociala relationer och över sitt sociala stöd antas alltså vara av betydelse för det personliga välbefinnandet, medan i det fall den äldre känner att den egna situationen bestäms av "mäktiga andra», kan i stället det subjektiva välbefinnandet minska. Att erhålla stöd från opålitliga källor som varierar i sin benägenhet att ge stöd och hjälp kan därför orsaka stress och spänningar och reducera den äldres känsla av att ha kontroll över situationen, vilket i sin tur kan bidra till minskat välbefinnande (Carstensen \& Lang 1997, Pitcher \& Hong 1986, jfr Diehl 1998, Willis 1991).

Hur äldre människor upplever sin livssituation, liksom deras val av aktiviteter och sociala relationer, såsom kontakt med familj och vänner, kan naturligtvis även påverkas av kön, ålder, klass, ekonomi, bostadens utformning m.m. (bl.a. Arber 2004, Carstensen \& Lang 1997, Heckhausen \& Lang 1996), men det har inte varit möjligt att beakta dessa aspekter i denna artikel.

\section{Studiens genomförande och beskrivning av informanterna}

Studien har inriktats på de äldres sub- jektiva erfarenheter av sitt vardagliga liv genom vad de själva berättar om sin livssituation och hur de hanterar den. Den baseras på tematiserade samtalsintervjuer och har alltså en kvalitativ inriktning. Analysen har begränsats till »kognitivt friska» äldre, vilka är i behov av hjälp och stöd i sitt vardagliga liv på grund av fysiska funktionsnedsättningar av varierande slag. Med "kognitivt friska" avses personer som inte har allvarliga minnesproblem eller skador orsakade av exempelvis olika demenssjukdomar.

Urvalet kan sägas utgöra en kombination av kriterieurval och frivillighetsurval. Utgångspunkten för studien är att de studerade individerna har hjälp från hemtjänsten, vilket utgör kriteriet på behov av hjälp och stöd. Urvalet baseras på en tidigare undersökning av hemtjänsten, där deltagarna i undersökningen bestod av personer, 75 år och äldre, i s.k. ordinärt boende (Hammarström 2002). Deltagarna tillfrågades om de kunde tänka sig att medverka i en senare intervjuundersökning, och drygt 150 av de 522 som besvarat enkäten angav i denna att de gärna skulle delta i en senare intervjuundersökning. Ca 40 personer uppvisade ett intresse för denna studie, och 29 personer har intervjuats helt eller delvis. Skälet till att inte delta i denna intervjuomgång var i huvudsak ytterligare "försämrad hälsa» enligt eget ordval eller att tidpunkten inte passade. Några hade avlidit. Samtliga intervjuade uppfyllde enligt vår bedömning inte kriteriet på att vara »kognitivt friska». Till grund för analysen ligger 21 genomförda intervjuer.

De intervjuade är i åldern 78-93 år; fyra är män och de övriga är kvinnor. Den över- 
vägande majoriteten är ensamstående och ensamboende; endast två personer (båda kvinnor) är gifta och sammanboende. De flesta har både barn och barnbarn, och några har barnbarnsbarn; sex personer är barnlösa. Uppgifterna om informanternas funktionsnedsättningar bygger på deras egna berättelser och inte en regelrätt mätning. Eftersom studien har inriktats på de intervjuades subjektiva erfarenheter av hjälp och stöd, har det inte varit centralt att definiera omfattningen av hemtjänstens insatser eller vårdnivå; några har daglig hjälp flera gånger om dagen, andra mer sällan. Förutom detta kan det förtjäna att nämnas att samtliga har varit yrkesverksamma åtminstone under någon del av sitt liv och även varit socialt aktiva och deltagit i föreningsliv, facklig och/eller ideell verksamhet m.m. De representerar både arbetare, högre och lägre tjänstemän, samt småföretagare, och samtliga yrkeskategorier är företrädda i de olika förhållningssätt som identifierats.

Under hela forskningsprocessen har Vetenskapsrådets etiska riktliner beaktats, dvs kraven på information, samtycke, nyttjande och konfidentialitet. Intervjuerna genomfördes under våren och sommaren år 2002 i de intervjuades hem och de varade mellan en och två timmar. De utgick från informanternas situation att vara i behov av hjälp och stöd. Informanterna tillfrågades om hur de såg på sin livssituation i allmänhet, och mer specifikt vad de ägnade sig åt på dagarna, kontakter med anhöriga och vänner, hur de såg på sin stöd- och hjälpsituation och på framtiden m.m. De transkriberade intervjuerna har analyserats i flera steg i enlighet med Creswells (1998) rekommendationer. Efter att oberoende av varandra ha summerat de olika intervjuerna för att därefter karakterisera respektive informant utifrån olika teman, har vi i ett senare steg jämfört och diskuterat våra respektive bedömningar för att nå en intersubjektiv överensstämmelse inför själva tolkningsfasen. Denna sista fas inriktades på det karakteristiska för de olika teman och förhållningssätt som identifierats i föregående analyssteg.

Flera olika teman har identifierats, varför vi i denna artikel har gjort vissa avgränsningar. Eftersom de intervjuade i huvudsak uppehöll sig vid sina upplevda begränsningar mer än vid sina möjligheter, är ett tema deras begränsningar i rumsligt avseende, och ett annat deras begränsningar i fråga om sociala relationer och socialt stöd. Ytterligare teman är huruvida de själva anser sig styra över sitt liv samt deras upplevda välbefinnande. Utifrån dessa teman har fyra olika förhållningssätt identifierats, vilka utgör resultatet av en empirisk renodling utifrån informanternas beskrivningar.

\section{Livssituation, förhållningssätt och välbefinnande}

De fyra förhållningssätt, som identifierats, har givits benämningarna De accepterande, De uppgiuna, De kämpande och De autonoma. De ger en ögonblicksbild av informanternas framställning av sig själva och sin situation, som avser intervjutillfället. De ska alltså inte ses som statiska beskrivningar men inte heller som olika faser i ett utvecklingsförlopp, vilket inte utesluter att äldre människor kan ha olika 
förhållningssätt under olika skeden av sitt liv.

\section{De accepterande}

De som givits benämningen De accepterande är samtliga ensamstående och har barn boende i närheten. De tillhör de äldsta informanterna och är i åldern 86-93 år. När de beskriver sina funktionsnedsättningar och problem, är det mer i förbigående och i samband med de aktiviteter och göromål de ägnar sig åt, även om de därmed inte bagatelliserar sina fysiska begränsningar. Framför allt ger de uttryck för att ha en bra livssituation:

Jag upplever min hälsa ganska bra, det är inga större fel. Det är lite kramigt i fötterna, men det kanske inte är så underligt vid mina år. Jag är nästan 87 år. [...] Jag har ju sinnena $i$ behaill, jag ser lite dåligt på ena ögat, men hörseln är bra. [...] Jag ser på min livssituation bra. Själv har jag inte den inställningen att jag vill härifrån som många säger, utan jag vill gärna fortsätta så länge hälsan är så pass god som den är. Det är egentligen inga fel. (Gustav)

Jag tycker att det är bra som det är faktiskt, det måste jag säga. Jag kan komma upp och komma ur sängen själv och klara mig själv och jag lagar min mat själv, såjag tycker det är bra, jag är nöjd. [...] Jag försöker leva mitt liv som det är bara, göra det bästa av det man har. (Disa)

Även om De accepterande ser sig som fysiskt begränsade och därför till viss del har minskat på tidigare aktiviteter utanför hemmet, ger de intryck av att de endast delvis låter sig begränsas rumsligt. De försöker upprätthålla olika aktiviteter, som hushållsgöromål och promenader, och de motiverar hushållsgöromålen med att det är roligt och promenader med att de mår bra av dem och att de får träna sina muskler. De läser också dagstidningar, löser korsord, lägger patiens och pussel eller handarbetar och deltar i vissa föreningsaktiviteter och/eller går på konserter och liknande. De framställer sig alltså som relativt aktiva genom att ägna sig åt sina tidigare intressen, som enligt Baltes \& Horgas (1997) kan påverka deras livskvalitet. Till skillnad från de övriga informanterna kan de också sägas se till sina möjligheter och inte bara sina begränsningar. Även om de framhåller vad de ägnar sig åt på dagarna, betyder det inte att de inte kan sakna tidigare aktiviteter, som att kunna promenera utan käpp, eller att vara på sommarstället så ofta som de skulle vilja. De ger emellertid uttryck för ett stoiskt förhållningssätt till detta, eller som en av dem uttrycker det: "När man inte orkar längre, så saknar man det inte på samma sätt som förr». Att de beskriver sig som rumsligt något mer begränsade än förr, behöver alltså inte betyda att de också känner sig rumsligt begränsade.

Sina relationer till hemtjänsten framställer De accepterande som neutrala. I huvudsak konstaterar de att de har hjälp, och säger mera i förbigåenden att "visst är det skönt att ha dem och veta att de kommeru, eller "man har inget val, man fär ta det som man fär det», men de tycks inte ha någon egentlig social relation till hemtjänstens personal eller någon önskan om detta: „Det är mycket 
vänliga människor. Det är ju ganska många olika personer som kommer, så man blir ju inte precis bekant med dem, men det finns ingenting att anmärka på\%.

De framställer det inte som något problem att ta emot hjälp vid behov utan snarare som naturligt. Däremot vill de inte be utomstående om hjälp: "Det är skillnad om folk erbjuder hjälp». När det gäller vänner och vänners betydelse påpekar De accepterande att vännerna försvinner när man är $\mathrm{i}$ deras ålder, samtidigt som de framhåller att de inte är så beroende av sällskap och inte känner sig ensamma. Erfarenheten av att vara kvarlämnad, att tillhöra "överlevarna«, vilket enligt Carstensen \& Lang (1997) kan erfaras som att livsrummet krymper, förefaller de se som odramatiskt. De framhåller i stället sina goda relationer till barnen, barnbarnen och andra släktingar. De egna barnen beskrivs som stödjande och som de som mestadels står för praktisk hjälp vid sidan av hemtjänsten, även om just omfattningen av konkret hjälp kan variera. De ger uttryck för att kunna ta emot barnens hjälp och be om den utan att känna ett hot mot den egna autonomin (jfr Carstensen \& Lang 1997, Heckhausen \& Lang 1996). När de berättar om sina barn använder de många gånger positivt värdeladdade ord, som uttrycker glädje över barnen och deras omtänksamhet:

Jag har två underbara flickor...ja, dom är fantastiska, fär jag säga, att hjälpa till.[...] Ja, döttrarna är fenomenala, de ser det [behovet av hjälp, vår anm.], innan jag själv ber om det. (Beata)

De accepterande säger sig inte bara vara tillfreds med sin nuvarande situation utan ser även framtiden an utan större oro för sin egen del, eftersom de betraktar det som de ser som "problem med hälsan« som något naturligt och något de får räkna med i sin ålder:

Man måste acceptera att en blir gammal.[...] jag är tacksam så länge jag ser, jag tycker inte att det är nainting att åldras, det tycker jag inte är nånting...Man känner det inte precis, det är ju så att en blir ju gammal och en blir ju skraltig. [...] Jag tänker, det fär ske som sker. (Iris)

Dessa informanter förefaller se sina funktionsnedsättningar som normala förändringar tillhörande åldern, och eftersom förändringarna är oundvikliga, accepteras de. Denna tolkning ska ses i förhållande till att de också upplever sig ha kontroll över sin tillvaro, inte minst över hur behovet av hjälp och stöd tillgodoses, trots att de inte uttryckligen uttalar sig om det, och det är mot denna bakgrund som deras uttryckta välbefinnande kan förstås.

\section{De uppgivna}

De personer som vi betecknat som De uppgivna tillhör de yngsta informanterna och de är i åldern 79-85 år. Fem är ensamboende, varav fyra har barn boende i närheten; en är gift och sammanboende och har barn boende långt från bostadsorten. Det som utmärker De uppgivna är att de beskriver sin situation som svår genom att »inte orka lika mycket som förr", att "minnas sämre», och framför allt att »inte kunna gå ut utan 
hjälp» och "vara beroende av andraw. De skulle kunna uppfattas som missnöjda utifrån enstaka citat, men vår bedömning mot bakgrund av hela intervjun, är att de mer ger uttryck för resignation än missnöje. De har tidigare varit mycket aktiva, inte bara i yrkeslivet, och tillfreds med livet och uppvisar stundom också viss galghumor. Samtidigt ger de uttryck för att sakna både kraft och motivation att söka göra något åt den situation, som de anser sig att ha »drabbats» av:

Det har hänt saker ... och då tycker jag att jag måste försöka få bättre ordning på mig, men det har inte blivit av. Men jag förstär ju att jag måste göra någonting själv för att komma igång... men jag kommer inte till skott. Det är det jag tycker är så jobbigt ... jag förstår inte varför jag släpper så. (Karolina)

De framställer inte sina funktionsnedsättningar på samma okomplicerade sätt som De accepterande, vilket i och för sig skulle kunna bero på att de har svårare funktionsnedsättningar i objektiv mening. Det som är av intresse här är emellertid deras subjektiva upplevelse av dessa, där en aspekt är att de anser att förändringarna kommit så snabbt och oväntat. Vi exemplifierar med Irene, som återkommer flera gånger i intervjun till sin synförsämring som skett väldigt hastigt. Hon tycker att det är svårt att inte kunna klara sig själv, t.ex. att »inte ens kunna sy i en knapp", och "inte se varor i affären«. Hon upprepar också flera gånger att hon saknar att inte kunna läsa längre, även om hon utnyttjar talböcker:

Jag kan inte acceptera det, det kom så plöts- ligt. Jag har inte successivt kunnat vänja mig. Men att man blir slö, man orkar inte. [...] jag går ingenstans, för jag ser inga ansikten, så jag ser inte vilka som sitter någonstans... Då går jag inte bort. Då sitter jag hemma för att det känns jobbigt. [...] När man inte kan läsa allting som står $i$ tidningen, så hänger man inte med på samma sätt, utan man blir liksom passiv.[...] Det är tungt, men det är så när man blir gammal.[...] Jag försöker arbeta på att jag ska vara nöd med det som varit.

De uppgivna uppehåller sig i relativt hög grad vid sina upplevda rumsliga begränsningar, framför allt att de inte kan gå ut på gården eller i staden utan hjälp, och de beskriver sig som inlåsta i bostaden:

Det som jag saknar är att komma ut lite, kunna sätta mig i solen, eller eventuellt ha någon som kommer så att vi kan gå ut $i$ lugn och ro, och gå lite grann och titta $i$ någon affär, gå och äta eller ta en fika, eller något, det skulle jag vilja göra... Nu kommer jag inte ut, nu kan jag inte, det går inte. (Hanna)

På grund av svårigheter att komma ut utan hjälp beskriver de sig som att de måste avstå från flera aktiviteter, som tidigare tillhörde deras intressen och som sannolikt skulle kunna bidra till deras livskvalitet (jfr Baltes \& Horgas 1997) : "Att inte kunna göra det jag har lust med, att alltid behöva känna sig beroende av andra, det är hemskt, hemskt». När De uppgivna talar om vad de gör på dagarna, uttrycker de sig i termer av tvång, t.ex. ifråga om att laga mat. Vissa använder ordvalet att de "fyller dagarna med att 
läsa och se på $T V$ ", eftersom "det inte finns mycket annat att roa sig med, när man är tvingad att sitta inne». Några uttrycker sig till och med så att de inte tycker att livet är värt att leva längre.

Trots att De uppgivna säger sig ha svårt att acceptera sin nuvarande situation, uppger de att de inte är oroliga för ökade krämpor, eftersom sådana hör till och »inte är något att göra åtw. Det kan tyckas något motsägande, men kan tolkas så att det inte är de fysiska funktionsnedsättningarna i sig som de anser vara mest besvärande utan konsekvenserna, såsom att känna sig inlåst $\mathrm{i}$ bostaden och därför inte kunna träffa andra människor: "Det har blivit ett väldigt stort problem den sociala isolering som blivit. Jag känner mig väldigt ensam, och jag behöver kontakt med andra människon.

Av De uppgivnas berättelser framgår att de inte har något omfattande socialt nätverk över huvudtaget. De jämnåriga vännerna beskrivs som "så gamla och sjuka själva" att de inte kan ses så ofta som de skulle önska, och i motsats till De accepterande uttrycker De uppgivna saknad över detta (jfr Carstensen \& Lang 1997). De uppgivna som har barn boende i närheten framhåller emellertid att de har relativt täta telefonkontakter med dem, samtidigt som de gärna skulle se att barnen "tittade upp» lite oftare. Deras barn anges inte ha så mycket tid att hjälpa dem med tjänster som att byta gardiner, köpa kläder m.m., dvs bistå med tjänster som inte hemtjänsten utför. Ett annat skäl är att barnen bor på annan ort eller utomlands. De uppger alltså legitima ursäkter till att barnen inte kan bistå med hjälp, vilket även framkommit i andra studier (Arber 2004). Dessa informanter ger också uttryck för att deras barn har svårt att förstå att de kan behöva hjälp och menar att om barnen inte själva ser deras behov, vill de inte heller be barnen om hjälp. Även om De uppgivna har emotionella band till sina barn, beskrivs alltså inte barnen som vare sig socialt eller praktiskt stödjande. Relationen till barnen kan sägas karakteriseras av ambivalens som inkluderar både en önskan om närhet och besvikelse (jfr Lüscher \& Pillemer 1998). Att i denna situation be sina barn om hjälp kan således i enlighet med Heckhausen \& Lang (1996) innebära en för hög social kostnad för dem och ett hot mot den egna integriteten.

Även om De uppgivna är medvetna om att de inte skulle klara sig utan den hjälp de får från hemtjänsten, uttrycker de sig i relativt kritiska ordalag, bl.a. över det de kallar för "fuskstädning", att "personalen inte kommer som bestämt", och de inte alltid får den "hjälp som det finns beslut på», samtidigt som det finns en ovilja att tala om hemtjänsten. Några uppger dock att de ses som krävande av hemtjänstens personal: "Det är så att jag är grinig och inte snäll bara för att jag säger till, det har jag fätt höraw. Den uttalade kritiken är dock uttryck för besvikelse snarare än regelrätt missnöje, vilket framkommer i citatet ovan, där Hanna ger uttryck för sin saknad över att inte ha fått komma ut en enda dag under den gångna våren och sommaren trots beviljat beslut om promenader. De uppgivnas berättelser tyder även på att de inte har någon egentlig social relation till hemtjänstens personal.

De uppgivna framställer sig som olyckligt drabbade, samtidigt som de tycks uppleva en viss osäkerhet och opålitlighet i stödet från både hemtjänstens och bar- 
nens sida. Även om funktionsnedsättningarna ses som oundvikliga, har de svårt för att acceptera de upplevda konsekvenserna. De ger intryck av att inte längre uppleva sig ha kontroll över sitt liv på samma sätt som tidigare, vilket kan bidra till deras uttalade låga välbefinnande.

\section{De kämpande}

De kämpande är i åldern 78-86 år; tre är ensamboende och en gift och sammanboende. Tre av dem har barn boende i närheten. Det som karakteriserar De kämpande är att de i motsats till De accepterande och De uppgivna uttrycker en motivation att överbrygga sina fysiska begränsningar och aktivt försöker förändra sin livssituation. I intervjuerna uppehåller de sig främst vid upplevda begränsningar av de funktionsnedsättningar, som var mest aktuella vid tiden för intervjun, samtidigt som de framhåller att de antingen har satt upp mål för att »komma tillbakau så mycket som möjligt (Katarina och Rolf), eller aktivt har förändrat sitt boende för att inte känna sig lika fängslade i bostaden som tidigare (Amalia och Rebecka), eller som Amalia uttrycker det: "Jag kände mig fängen när jag inte kunde komma ut när jag ville». Efter att ha flyttat till ny lägenhet tycker hon att det är "mycket bra, för jag kan komma ut. Jag bor pånedre plan. Min son var ju emot det, men det var tur att jag gjorde det«. Hon berättar också att hon har börjat bekanta sig med de nya grannarna.

Rolf, som haft en stroke och därför sitter i rullstol, framför att det har tagit längre tid att nå de uppsatta målen än han tänkt från början, och att han därför har sänkt anspråken något. Han tycker ändå att han har gjort stora framsteg:

Först ...var det att jag skulle kunna gå själv och vara ute och så, men det har jag övergett nu. Nu räcker det om jag kan gå lite grann med hjälpmedel.[...] Jag trodde att det här klarar jag på en månad. Det har gått sju månader och jag kan inte gå själv än, jag kan skriva och jag kan äta, det kunde jag inte heller då. Jag kan ju resa mig, jag har handtag i väggen, jag kan rulla ut på balkongen, jag går på toan själv, och jag gör toalett och tvättar mig.[...] Jag tycker själv att jag har kommit ganska långt.

De kämpande tar för givet att de kommer att få ökade krämpor i framtiden, eftersom "det är en del av livetw. De oroar sig emellertid inte särskilt för det utan framställer det som något som de får ta itu med när det händer. Rebecka, som har en kronisk sjukdom, uttrycker sig på följande sätt:

Jag lever med den sjukdom jag har och jag försöker lära mig så mycket jag kan, och jag frågar läkarna och jag frågar och frågar... jag ska försöka klara av det här själv...jag vet ju att jag kommer att försvinna med sjukdomen, men jag tänker inte när. Jag ska bli 100 àr.

I sin relation till hemtjänsten anser de sig få stöd att klara vardagen, men de uttrycker samtidigt viss kritik mot städningens utförande, ledningen och regelsystemet: "Jag vill att det ska vara flexibelt ... Jag har råkat ihop med ledningen flera gånger ... Hemhjälpen ska vara en hjälp till självhjälp, men när 
man inte orkar, vad gör man då». "De ställer ju upp med det mesta, ... men att inte kunna göra någonting utöver det som står på pappret. Om jag tappar ett glas vatten, så torkar ingen upp det». De är ändå förhållandevis nöjda med relationen till vårdbiträdena, även om det uttrycks i neutrala ordalag.

Oavsett de rumsliga begränsningar som De kämpande stundom kan uppleva, beskriver de sig inte som socialt begränsade. De upprätthåller sociala relationer med anhöriga och/eller vänner. De som har barn uppger att kontakterna med dem är viktiga, dock utan de positivt värdeladdade ordval som De accepterande gav uttryck för. De deltar i familjehögtider tillsammans, åker på utflykter m.m., och barnen hjälper till med olika tjänster, vilket framställs som relativt okomplicerat: "När jag ber honom kommer han«. Förutom att barnen beskrivs som stödjande, kan De kämpande både ta emot och be barnen om hjälp utan att uppleva det som ett hot mot den egna integriteten (jfr Carstensen \& Lang 1997, Heckhausen \& Lang 1996).

De betonar också betydelsen av att ha kontakt med goda vänner. Även goda grannkontakter värdesätts. Det betyder dock inte att de ber vännerna om hjälp: "Jag tror inte att det är så lyckat». De motiverar det med att de inte vill stå i tacksamhetsskuld till nära vänner. Även om vänner beskrivs som betydelsefulla och hjälpsamma och därför kan ses som både emotionellt och praktiskt stödjande, finns det här uppenbarligen en gräns för vad som kan upplevas som ett hot mot den egna autonomin.

Även om De kämpande säger att livet inte alltid varit lätt på grund av deras funktionsnedsättningar, som stundom upplevts som "jobbiga", uppger de sig vara relativt nöjda med sin situation. Deras uttalanden i det avseendet kan ändå tolkas som att de inrymmer ett "trots allt». Samtidigt tycks de drivas av en önskan om att ha kontroll över sin tillvaro och agerar utifrån denna önskan och har, som Tanner (2001) uttrycker det, en »fighting spirit». De kämpande framställer sig alltså som medvetna aktörer med inneboende resurser.

\section{De autonoma}

De intervjuade som givits benämningen De autonoma är samtliga ensamboende och i åldern 84-91 år; två har barn boende i närheten och sex personer är barnlösa. De skiljer sig från De kämpande genom att inte sträva efter att förbättra sin situation för att överbrygga sina rumsliga begränsningar utan i stället betona sitt oberoende. När de beskriver sina funktionsnedsättningar, talar de om de medföljande begränsningarna i viss mån motvilligt och hänför inte alltid dessa begränsningar till sig själva utan till faktorer i omgivningen, såsom trapphusets beskaffenhet, tunga dörrar, eller att hemtjänsten inte alltid bistår med det som de förväntar sig. I stället framhåller de att det egentligen inte är så stora fel med dem och att de klarar sig bra. De vill emellertid själva kunna styra sitt liv och bestämma över sin situation. Detta förhållningssätt exemplifieras nedan genom Alva och Ida, vilka båda sitter i rullstol och inte kan komma ut utan hjälp, vilket innebär att de mestadels är sittande inne.

Alvas funktionsnedsättningar innebär att hon måste be om hjälp med allting, och 
hon upplever det "fruktansvärt att vara beroende av hjälp och be om hjälp», och drar sig för det, samtidigt som hon betonar att hon egentligen är frisk:

Så nu sitter jag här, det är nu, ja det är på tredje året som jag sitter här och inte har varit ute, annat än när jag har besökt [sjukhus, fotvården etc.] Sen sitter jag här hela dagarna förstår du utan att komma ut eller nånting. ... Men i övrigt är jag alldeles frisk, alldeles frisk, alla värden är bra.

I sin önskan om att vara oberoende har Ida svårt att be om hjälp och framhåller att hon lagar mat, diskar och bäddar själv trots svår värk:

Jag har faktiskt lite svairt att be om hjälp, så det drar jag mig för. Man ska vara duktig $i$ alla fall.[...] Jag har alltid velat bestämma själv... nästan. Och det har jag kunnat göra också.

När det gäller vänner har några av dem många vänner och uttrycker också sin tillfredsställelse med det. Andra har ett mycket litet socialt nätverk men framställer sig ändå inte som socialt begränsade. Liksom De accepterande konstaterar de att "när man kommer upp i åren, försvinner ens vännerı. De som inte har så många vänner uttrycker inte någon större saknad eller längtan efter ett större umgänge och hänför detta till att de "inte har så stort behov av sällskap». De som har barn uppger att kontakterna med barn och barnbarn betyder mycket, samtidigt som det framkommer att det ibland föreligger vissa konflikter i relationen till barnen.
När det gäller relationerna till hemtjänsten går uppfattningarna åt olika håll. De är både nöjda med den hjälp de får och samtidigt kritiska mot arbetsledning och bristande organisation, främst över att fattade beslut inte följs, att det är "många olikau, att personalen "glömmer att kommau, "okunnig personal« m.m. De anser sig också ha rätten att ställa krav: "Har man varit van att vara väldigt självständig och så där, så är det klart att man kanske har andra krav också, det fär man ta med i beräkningenu. Den oro de hyser är mer förknippad med hur de ska bli omhändertagna när de blir sämre än de är idag, eftersom "det är som det är inom vården«:

Men jag blir arg på att situationen är så här, att vi gamla ska fä lida för det.... Ibland undrar jag hur det ska gå, när man känner sig sämre... det blir ju en annan fråga då, om man blir beroende av mera hjälp. (Rita)

Oron för den framtida hjälp- och vårdsituationen har inte framkommit på motsvarande sätt bland de övriga intervjuade och skulle kunna sammanhänga med att De autonoma inte har egna barn eller andra släktingar annat än undantagsvis, vilka skulle kunna komplettera hemtjänstens insatser. De autonoma säger dock att de i dagsläget har det relativt bra trots sina krämpor, även om det inte alltid är »så roligt». "Ökade krämpor kommer som de kommer« vilket de säger sig "ta med roк. De har dock en önskan om att få vara »klara i huvudet».

De säger sig alltså vara relativt nöjda med sin livssituation, vilket torde kunna tillskrivas deras starka önskan om att vara oberoende och ha egen kontroll. Samtidigt 
kan man spåra en ängslan bland dem över att i framtiden förlora den kontroll över sin situation, som de nu ger uttryck för att ha.

\section{Diskussion}

I analysen har vi alltså kunnat urskilja olika mönster avseende vad de intervjuade personerna berättar om sin livssituation utifrån upplevda rumsliga och sociala begränsningar, sociala relationer och socialt stöd samt välbefinnande, vilket har relaterats till vår bedömning av deras upplevda känsla av att ha kontroll över sin livssituation. Deras berättelser speglar olika förhållningssätt och strategier att hantera och bemöta de upplevda konsekvenserna av sina funktionsnedsättningar. Bilden av hur äldre personer i behov av hjälp och stöd ser på sin vardagliga livssituation är alltså sammansatt, och studien belyser den heterogenitet som kan finnas, framför allt i fråga om upplevelse av socialt stöd och kontroll i relation till rumsliga begränsningar.

De intervjuades berättelser belyser att deras upplevda välbefinnande kontextuellt hänger samman både med funktionsnedsättningarnas upplevda konsekvenser i rumsligt och socialt avseende, och hur de uppfattar möjligheterna att få stöd och hjälp och att känna att de har kontroll över sin situation. Det centrala i studien är därför de identifierade skillnaderna mellan informanterna i hur de beskriver konsekvenserna av sina funktionsnedsättningar $i$ relation till sina sociala relationer och det sociala stöd de erhåller.

Även om man inte ensidigt kan se till den självupplevda funktionsförmågan i rela- tion till de äldres välbefinnande, förefaller informanternas subjektiva upplevelse av instängdhet och deras möjligheter att förflytta sig från bostaden och därmed möjligheterna att bibehålla personliga intressen och sociala relationer ha stor betydelse, både för hur informanterna ser på sitt liv och för deras välbefinnande, ett förhållande som även Grenier (2005) funnit. Känslan av instängdhet utgör ett centralt tema för framför allt De uppgivna, och det finns också i bakgrunden i De autonomas och De kämpandes berättelser. De hanterar dock situationen på olika sätt. De accepterande är de enda som inte ger uttryck för denna känsla, och kan knappast sägas vara det heller enligt vår bedömning, eftersom de kan gå i trappor och gå ut och promenera, om än med visst besvär.

Givet de rumsliga konsekvenserna, illustreras genom de fyra förhållningssätten också hur relationen till barnen tillsammans med hemtjänstens upplevda stöd kan samverka och på skilda sätt sammanhänga med de äldres välbefinnande och känsla av att ha kontroll över sin situation. De accepterandes förhållningssätt kan delvis förstås i relation till att de ger uttryck för att se sina barn både som ett emotionellt och praktiskt stöd och även kan sägas uppvisa viss tillit till hemtjänstens stöd, vilket tillsammans med deras upplevda fysiska rörlighet, om än begränsad, kan bidra till en känsla av att ha kontroll över tillvaron och deras öppet uttryckta tillfredsställelse med sin livssituation (jfr Antonucci \& Akiyama 1997, Carstensen \& Lang 1997, Diehl 1998, Horgas et al. 1998, Pitcher \& Hong 1986, Willis 1991). Även De kämpande framställer sina barn som stödjande ifråga om möjligheter 
att minska den upplevda instängdheten och att upprätthålla sociala relationer, och de ger delvis även uttryck för att hysa tillit till hemtjänsten. Detta förhållande kan tillsammans med deras "fighting spirit» bidra till att de upplever sig ha tillräcklig kontroll över sin tillvaro för att de ska beskriva sig som relativt nöjda med livet, trots en i övrigt ganska "jobbig» situation (Burnside 1993, Tanner 2001). För De accepterande och De kämpande tycks alltså hemtjänsten och de egna barnen komplettera varandra på ett gynnsamt sätt i förhållande till deras respektive funktionsnedsättningar.

För De autonoma och De uppgivna utgör emellertid hemtjänsten huvudkällan till deras hjälp och stöd. De autonoma hänför sin upplevda instängdhet och bristande möjligheter att upprätthålla tidigare intressen och sociala relationer till utomliggande faktorer mer än till de egna funktionsnedsättningarna. Deras förhållningssätt kan vara ett sätt att bibehålla känslan av att ha kontroll över sin tillvaro och att upprätthålla sin självständighet, vilket också kan ses mot bakgrund av att de i huvudsak inte har egna barn utan i stort sett är hänvisade till hemtjänsten, som stundom upplevs som ett opålitligt stöd (jfr Carstensen \& Lang 1997, Diehl 1998, Pitcher \& Hong 1996, Willis 1991). De autonoma kan emellertid, enligt vår bedömning, utgöra en "riskgrupp» för minskat välbefinnande, i det fall de skulle få känslan av att inte längre ha kontroll över sin vardagssituation. De uppgivna, som beskriver sig som drabbade av omständigheter som de inte har kontroll över, framställer sig som fängslade i bostaden utan så stora möjligheter att upprätthålla tidigare intressen och sociala relationer. Deras förhållningssätt i detta avseende kan ses i relation till att de inte heller upplever sig ha så stort stöd från de egna barnen samtidigt som de uttrycker brist på tillit till hemtjänstens stöd. Dessa omständigheter kan tillsammans bidra till deras uttalade låga välbefinnande (Carstensen \& Lang 1997, Diehl 1998, Pitcher \& Hong 1986, Willis 1991). Deras vardagssituation tycks dem övermäktig, och vi bedömer dem som de mest sårbara av de intervjuade personerna.

Som framgått, hanterar informanterna sin situation på olika sätt, och de har olika strategier (jfr Horgas et al. 1998). Kontextuellt sammanhänger deras strategier delvis med de beskrivna konsekvenserna av deras funktionsnedsättningar, där upplevelsen av att vara "inlåst i bostaden" och inte ha tillgång till de sociala möjligheter som "utelivet« kan ge, tycks utgöra en viktig komponent, vilket också ska ses i relation till deras möjligheter att få stöd och hjälp till detta. De accepterandes strategi är att avstå från vissa aktiviteter, samtidigt som de fortsätter med andra antingen med hänvisning till att det är roligt eller för att det är nyttigt, vilket kan förstås som en uppehållande strategi. De kämpande har till skillnad från de övriga informanterna uttalade mål, och för att söka minska de upplevda konsekvenserna av sina funktionsnedsättningar eller för om möjligt återfå ökad rörlighet, har de aktivt sökt lösa sin situation. Både De accepterandes och De kämpandes strategier kan ses som medvetet problemlösande, om än på olika sätt. De autonoma kan karakteriseras som jämförelsevis mer emotionsinriktade genom att betona sin självständighet och hänföra konsekvenserna av sina funktionsnedsättningar till utomliggande faktorer 
i stället för till egna begränsningar. Detta förhållningssätt kan ses som en aktiv strategi för att bibehålla sitt välbefinnande. De uppgivna däremot uppvisar egentligen inte några aktiva strategier i hanterandet av sin vardagssituation. De ger intryck av att mer eller mindre passivt ha valt bort, eller bortsett från möjliga alternativ till handlande.

Teoretiskt skulle skillnaden mellan de olika förhållningssätten även kunna förstås utifrån åldersnormativa föreställningar, om huruvida man är i fas med allmänna stereotypa föreställningar om vad som är "normalt» eller "icke normalt" för människor i ens egen (kronologiska) ålder (Hansson \& Carpenter 1994, Heckhausen \& Lang 1996). Som exempel skulle De accepterande, som tillhör de allra äldsta, kunna se sig själva som »i takt» med sina jämnåriga i bedömningen av sin egen livssituation, medan De uppgivna, som tillhör de yngsta, kan uppleva sig vara »i otakt» i jämförelse med sina jämnåriga. Oavsett om detta samband med ålder beror på tillfälligheter på grund av det empiriska materialets begränsade storlek eller inte, har emellertid denna tolkning den svagheten att De kämpandes respektive De autonomas förhållningssätt inte lika enkelt kan förstås utifrån åldersnormativa antaganden. Dessutom, om även s.k. äldre-äldre i en mer omfattande studie skulle uppvisa ett förhållningssätt, som skulle kunna liknas med De uppgivnas, skulle en tolkning utifrån åldersnormativa föreställningar vara mindre relevant. Mer sannolikt är att informanternas förhållningssätt också kan hänga samman med hur de ser på åldrandet, både generellt och för egen del, vilket är föremål för en kommande analys (Torres \& Hammarström).

\section{Referenser}

Antonucci, T.C., Akiyama, H. (1997) "Social support and the maintenance of competencer. I S.L. Willis, K.W. Schaie \& M. Hayward (red.) Societal mechanisms for maintaining competence in old age, s. 182-206. New York: Springer Publ. Comp.

Arber, S. (2004) "Gender, marital status, and ageing: Linking material, health, and social resocurces». Journal of Aging Studies, 18, s. 91108.

Baltes, M.M., Horgas, A.L. (1997) „Long-term care institutions and the maintenance of competence: A dialectic between compensation and overcompensation". I S.L. Willis, K.W. Schaie \& M. Hayward (red.) Societal mechanisms for maintaining competence in old age, s.142-164. New York: Springer Publ. Comp.

Burnside, I. (1993)»Healthy older women - in spite of it all.. Journal of Human Aging, s. 9-24.
Carstensen, L.L. (1992) "Social and emotional patterns in adulthood: Support for socioemotional selectivity theory». Psychology and Aging, 7, s. 331-338.

Carstensen, L.L., Lang, F.R. (1997) „Commentary: Social relationships in context and as context: Social support and the maintenance of competence in old agew. IS.L. Willis, K.W. Schaie \& M. Hayward (red.) Societal mechanisms for maintaining competence in old age, s. 207-222. New York: Springer Publ. Comp.

Creswell, J.W. (1998) Qualitative inquiry and research design: Choosing among five traditions. London: SAGE Publ.

Diehl, M. (1998) „Everyday competence in later life: Current status and future directions". The Gerontologist, 38, s.422-433.

Grenier, A.M. (2005) »The contextual and social locations of older women's experiences of disa- 
bility and decline». Journal of Aging Studies, 19, s. 131-146.

Hammarström, G. (2002) »Hemtjänsten behöver mera hjälp. Äldre hjälpmottagares erfarenheter av hemtjänsten". Socialmedicinsk Tidskrift, 79, 3, s. 271-284.

Hansson, R.O., Carpenter.B.N. (1994) Relationships in old age: Coping with the challenge of transition. New York: The Guilford Press.

Heckhausen, J., Lang, F.R. (1996) "Social construction and old age: Normative conceptions and interpersonal processes». I G.R. Semin \& K. Fredler (red.) Applied social psychology, s. 374340. London: Sage.

Horgas A.L, Wilms H-U. \& Baltes M.M. (1998) "Daily life in very old age: Everyday activities as expression of successful living". The Gerontologist, 38, s. 556-568.

Lüscher, K., Pillemer, K. (1998) „Intergenerational ambivalence: A new approach to the study of parent-child relations in later lifer. Journal of Marriage and the Family, 60, s. 413 - 425.

Pitcher, B.L., Hong, S.Y. (1986) „Older men's perceptions of personal control: The effect of health status". Sociological Perspectives, 29, s. 397-419.

Tanner, D. (2001) "Sustaining the self in later life: Supporting older people in the community". Ageing and Society, 21, s. 255-278.

Torres, S., Hammarström, G. (Kommande). "Speaking of limitations while trying to disregard them: A qualitative study of how diminished every day competence and aging can be regarded». Manus accepterat för tryckning i Journal of Aging Studies.

Willis, S. L. (1991) "Cognition and everyday competence». Annual review of gerontology and geriatrics, 11, s. 80-109.

\section{Summary}

\section{Life situation and approach to everyday life: a study of elders in need of help and support}

This study aims to shed light on how elders who are in need of help and assistance in their everyday lives perceive their situation. The data were collected through qualitative interviews with people between the ages of 78 and 93. Four themes have been identified (i.e. acceptance, resignation, resistance and autonomy) with regard to the implications that being in need of help and assistance has for one's life situation; the strategies elderly people use to handle their limitations; the sense of control or lack of control that these strategies seem to bring about, and the overall sense of wellbeing or lack of well-being that results from them. Our findings suggest that physical limitations do not in and by themselves bring about a sense of being socially and/or spatially limited. Fairly distinctive ways of relating to the help and support one receives from one's adult children and home-help care services also seem to go hand in hand with each of the themes in question. 